\title{
The Implications of Digital Transformation in Developing Human Resources in Business Practice in Indonesian: Analysis of the Publication
}

\author{
Kosasih \\ Universitas Sangga Buana, Indonesia \\ Email: kosasih@usbypkp.ac.id \\ Irma Rasita Gloria Barus \\ College of Vocational School of IPB University, Indonesia \\ Corresponding author email: irmabarus@apps.ipb.ac.id
}

\author{
Alim Hardiansyah \\ Institut Sains dan Teknologi Al Kamal, Indonesia \\ Email: alimhardiansyah@ista.ac.id
}

\begin{abstract}
This exploration's center target is to comprehend the ramifications of specialized data to improve HR for organizations in Indonesia. Thus, we gathered information from challenged distributions from 2010 to 2021. After the information was gathered, we investigated it with a phenomenological approach so that responses to the examination were gotten with legitimate and reliable standards. Before we can get to the discoveries of the current information, we should comprehend the inquiries; in the information examination measure, we included coding, top to bottom assessment, and summing up the information discoveries. We focus on optional information with a subjective enlightening methodology with as much direction as information from Google students, ERIC distributions, Google Docs, and different sources. Specialists join our investigation manage to check on innovation studies and applications in maternity care social examinations. In light of the information and discoveries, we presume that the associations we contemplated decided to apply and change innovation in birthing assistants to improve HR's dependence on the standards of utility, accommodation, proficiency, and profitability of the actual innovation.
\end{abstract}

Keywords---digital services, human resource improvement, review studies, technology transformation.

\section{Introduction}

The implications of digital transformation in human resource development in Indonesia's business functions are the most exciting issues to study (Fenech et al., 2019; Kosasih, 2019). Therefore, this issue is significant to be studied to gain new understanding and knowledge for many groups; business people, policymaking, and Reis et al. (2018) predict that the study of digital transformation will be a guide for many business drivers and efforts to strengthen human resources in business. Because business digitization is a course that has become a trend in all sectors of human life, the business sector is not left behind, and increasing human resources to support business practices will reform all forms of business in the modern business era. For business practitioners and decision-making circles, digitalization in the business world is a new technological transformation that functions to create a sophisticated approach to business activities and effective HR.

Gupta et al. (2020) analyze digital trends that are now becoming models and insights in getting the way businesses are run with new systems and methods in achieving business profit goals. So, connecting to the above idea, digitalization is also something cutting-edge strategies in business creation and useful experiences for 
customers to meet their needs. This technology is capable of supporting business activities and operational HR (Westerman et al., 2014; Loebbecke \& Picot, 2015; Dalenogare et al., 2018; Putra et al., 2020). Digital applications are not just brands but are a way to transform how business practices work to achieve profit and sustainability. There is anything that when we talk about digital applications, we have to consider the function of technology, how do this functions, how digital does function for human businesses, and how digital transformation brings happiness to customers? How businesses practice change in the process, how businesses look for new models, and how businesses can reach the stock market or traditional market and go to the high tech market. How can a business get into social media marketing, and how can it be assisted by digital, which becomes an automatic operation? How can business be assessed as a solution even by all business drivers operated with automated data? (Parviainen et al., 2017).

The question of how to run a business that adapts to digital trends is so potential one. Maybe business people should think about what they can do to build a successful digital business (Harmon \& Trends, 2010). So, first of all, as business people, they must build strong entrepreneurs. It means that as a businessman, there must be an entrepreneurial mindset and high enthusiasm. It must have a managerial spirit to organize sustainable resources and have a leadership spirit that functions incorrectly in business practices. So with the help of digital business tools, it will function in best practices. Then build a robust digital strategy so that all potential and opportunities can run optimally and understand how the business continues - other things like how to require a business that is supported by digital. Schwertner (2017) is a business model in the advanced era by incorporating digital to transform a profitable business. Next, make the final step to building a profitable business using or supported by digital transformation. Along with building a business that is supported by online or digital applications, business people also have two things; how a business strategy in order to win the competition in the global market in global customer demand and how business is not only concerned with profit but is sustainable to create a good business climate and create a healthy strategy.

So when using digital applications, this strategy means that business people must think about technology by transforming them to be successful in business practices, how technology can create new competitiveness in products and services. Palmer \& Flanagan (2016) said that sustainable business through looking at goals for business people, customers, and the environment Businessmen could bring a strong image in products or processing and then how strategy can drive, direct and manage the business to create more profits and more profit as a result of technological transformation. Likewise, they also think about things as tactics to play. So that is how to achieve profitable business goals and sustainable stopping (Scott, 2017; Baum, 2015; Cardon \& Stevens, 2004).

Mazzone (2014) notes that every business must think about using digital or die. He sees today's business can turn into a profitable one when digital exists. When it comes to digital chains, digital must be able to change the business to find its purpose, so before that, business people must understand how and what digital is, for example, when we think about digital change business practices. We have digital tools to incorporate artificial intelligence into business practices, how human resources in business activities can support and can help use technology to support operations so that digital transformation can support seller products and services at once (Morkunas et al., 2019; Montecchi et al., 2019). One of the business customers can be provided, for example, how customers can interpret business online so that how the technology applied by the business can save customers either in time or finances or energy or vice versa safely. So, the transformation is so effective in business operations that sales businesses consider using digital to transform marketing, for example, how they support customers, how these details can support business strategy, and help companies make decisions, and improve overall business operations (Gibler \& Lindholm, 2012; Chen et al., 2004; Miles \& Snow, 1984).

So when we talk about business in the era of intense competition, we have to think about how technology can support operations to produce products and handle services with quality human resources, then the idea of technology adoption must be considered. Krasnov et al. (2019) are very precise when updating digital communication modeling, promoting all products and services to be prioritized essential. Otherwise, consumers will leave. Likewise how technology applications can support the factors of product marketing and market evaluation functions. Another part of the promo or digital marketing we have to think about how digital can support such as social media marketing platforms is very very useful how we can hire such as marketing systems that involve role models or influencers, how to create correct addresses such as email or how people can market (Bhanot, 2012). When we do advertisements, we have to do what content is relevant for the business and then how the possible customer search where we are and how they can communicate and conduct the transaction, how they can conduct like payment effectively using the digital approach and yeah making sure when there is a marketing product that is a payment that is will be a goal profitable.

In another aspect, when we say technology and transformation in business, we must train human resources in the coming years how businesses have integrated business applications. However, the lack of human resources who are 
behind the technology is useless. So, they can take digital benefits to transform services and business operations in a country that is currently forward (Cascio, 2015; Malik, 2019; Schuler, 1992; Thakur, 1999). because online technology is possible to support businesses owned by artificial intelligence machines that are trending in the business world that are supported by automated robots to optimize business productivity. Tambe et al. (2019) said that the artificial intelligence aspect is excellent if supported by well-organized human resources to produce management ready to face the company's challenges and future glory. Using computers can be done according to practical business, all of which support digital transformation as it will last for many years to come in any business (Komninos, 2006). When we talk about things or transformations, there will be like how we can change how we can translate how we can move, or we can reflex how we can like rotating and deleting things circle so that is how we do it so how can we implement one of the four types of transformation in business practices in the coming year (Lewandowski, 2016).

So when we think about transformation in business, we also have to consider the adequate number of human resources or operational methods that must be followed. Briscoe (2004) agrees that reliable HR in an increasingly globalized and flexible business in HR management should become a policy and best practice for companies to go the global enterprise. For example, digital transformation involves machines in business practices. Business people must think like standing on the customer's side or client first (Bratton \& Gold, 2017). Whatever we apply in business, the manager must think about what the value is for the customer, what is the value for us, what is the value of balance because a healthy business is not only looking for what we call benefits for us in the form of monetary gain but also suitable for customers, both for employees and even good for the environment. So keep balance and continuity. Then business people must consider how the culture in the organization is healthy using technology. But to think about how it functions in an organization or business operations and then we have to consider such as business management which is supported by sufficient human resources which are continuously trained and skilled (Noe et al., 2017).

How digital information applications can support management changes to be great or better can also impact functional literacy changes. Then the business must consider what technology is relevant or not. DiPietro \& Wang (2010) noted that a fundamental problem in applying technology incorporate businesses is the positive impact and implications for business governance that are not pleasing to consumers. Then we must be able to integrate or balance the business approach. Then how about excellent service to customers. Businesses must see during business translation time and how things that impact the application of technology in logistics and supply systems change during operations so that they all face digital chains and transformation. So that it can ensure the business runs smoothly to achieve its goals. Now business people turn to digital transformation and human resource development; Digital change can transform organizational processes into automated databases with technology support through digital transformation. Tarabasz et al. (2018) suggest that digital transformation trends become smart solutions when business people want to reach as many potential customers as possible. The technological transformation will not be successful if the human business resources do not have the right digital insights and trends.

A system used in an organization is not only to achieve goals that look good and luxurious, but any system to get success. Schuler \& Jackson (2014). Then what is a digital chain is a successful human resource with technology without the support of HR remains a target. Consolidation of superhuman resources is essential so that technological means can function to achieve the final goal, useful for many parties. As a technology, it can offer data to support HR management's optimization function (Westerman et al., 2014). How does management function well in an organization to benefit from an applied system. So payroll and development are essential so that the company's inability to provide rewards. For example, how HR recruits or cuts contracts, then all of that is responsible to HR who can support technology and transformation so that in the future there is no manual so everything must be automated and the database is inadequate technology with measurable leanings (Drew et al., 2016).

According to Ismail et al. (2017) transformation efforts in digital business strategy will change the way companies operate. The question is, can digital technology transform and bring resources and resources into viable practice. Technology support will not stop business transformation so that business people understand better the digital changes in human resources that are useful in practice and increase the capacity of company development. The main problem is the impact of the transformation of technology into human resources in business. Digital technology can optimize small functions. It can help make the transformation and regular transactions too and make progress today and again, digital can improve management and then can make system improvements if supported by technology (Westerman et al., 2014).

Kavanagh \& Johnson (2017) companies in the technology era cannot avoid information-based work in improving their human resources. At least the technology is in the basics of the application to efficiently face the challenges of the future direction of competition challenges. Because it is clear here where technology can support business 
functions that can be adopted to improve human resource management, such as digital technology platforms to manage new staff recruitment, promote staff, choose technology can also contact management in supporting the HR capacity building section. Technology is also capable of planning, such as obtaining benefits and support from human resource information systems through analytical inability. Moreover, human resources and heavy work are supported by technology, for example, in day-to-day handling administration, such as formulating company policies, recruiting new employees and old employees. The workplace and other organizational functions are HR duties relevant to digital transformation management best practices (Tyson, 2014).

When we adopt technology in business, we must know what functions can be done by adopting this technology (Hsu et al., 2014). So that with the public's understanding of information technology, we can make many innovations in business practice, with useful technological innovations. Of course, it will increase the data, making the process work faster and speed up data distribution. Then innovation also brings a profitable business to run successfully, and also innovation can provide added value that allows quality and, of course, the relativity booster system. When talking about financial improvements and the economic sector, there are many financial functions, for example, how purchases can be made very quickly (Remund, 2010). How can finance be productive, how contributions can give precisely where accounting is in the economy, how personnel or human resources can achieve as a management function, how we can utilize flat tools and people in economic management, and how money can be managed and profitable futures and manageable. When does business technology think less logic think about how software can perceive. How technology can handle good communication by using a smartphone with a system, how can it trust the accounting system, and how it can do it in logistics and inventory so that it does all the wrong things when doing business work (Vermesan \& Friess, 2013).

\section{Business in Indonesia}

Before this technology-based business study goes any further, we will briefly describe a typical business understanding. Understanding technological transformation in the Indonesian business environment certainly has differences with business conditions in other places (Capnary et al., 2018). According to our observations, changes in business practices assisted by digital technology have also colored business practices in Indonesia, especially technology adoption at the primary level. The increasing trend of computerized innovation to all business areas in the country generally changes business insight and orientation of both business people and consumers (Hotho \& Champion, 2011). The perspective of working and delivering incentives to clients is characteristic of the advanced era of business. Researchers believe that changes in the application of technology to business practices will impact every field of business. Moreover, what will happen to business culture in an era of technological change? The answer is to present technology to transform consumer services and business actors' HR governance more precisely (Fountain, 2004).

Furthermore, when thinking about digitalization efforts in business activities, we must consider the following points. Understanding business culture in Indonesia is indeed a broad theme to study (Campbell et al., 2015). We also need to limit it to limited study themes. In this article, we will discuss ways to adapt technology to business in Indonesia. Because the province's area from west Aceh to eastern Papua, Indonesia is the most dominant with a very heterogeneous culture, so that it has an impact on the way business is run. This condition refers to the many fields that can be implemented in Indonesia, which have a very high consumption culture. For example, how life and business are mixed from unique old traditions with various foreign influences from technology, business is slowly formed (Haron, 2016).

As we have explained above, changes in advanced technology will impact all fields, especially how doing business involves applying the latest technology (Joseph, 2016). We will focus on technology trends that spread to business people, especially HR innovation efforts. Nowadays, it is not comfortable to sell goods without technology, even without technology, even if the basics are still the business will be left out of consumers' reach. Selling almost every product and service is a new and useful way and model that expresses consumer society's condition and readiness towards modernity of industrial and economic business (Jeong et al., 2017).

With the characteristics of superior products, Indonesia will still be able to compete. Likewise, consumers will demand good marketing by adopting technology as a practical strategy. There are indeed many ways, but digital technology applications will be the newest choice in Indonesia. Admittedly all business people think of going there with technological readiness as the circumstances demand. Indonesian young people have a different way of looking at business from the older generation who do not know how to think and act to adopt technology, working business with modern business day methods. 
For example, the technology culture lately has tantalized business people, plus a pandemic period, perhaps the most famous in the field of fabric. Almost everyone in Indonesia knows about it. Many online shops sell fake batik at a lower price; people are happy to get it (McKerchar \& Evans, 2009). Meanwhile, some people have difficulty making technology to attract the younger generation, and some understand doing business with assisted technology. Some groups argue that if doing business can apply technology to increase human resources, they will progress quickly. When technological innovation develops rapidly, many new corporate organizations will be easily famous, new cultures and individual behaviors change, including doing business and doing transactions. It will also influence social trends, make them easier to market to or even present new models and styles accessible to a broad audience.

This is likely to occur in several other frugal and practical practices (Rosadi \& Tahira, 2018). Indeed, no one has consistently and for a while being able to advance in an era of increasingly tight business with rivals. Fortunately, a group of young businesspeople is starting to create innovative marketing products that can meet potential consumers with goods and producers. The young people will try to make marketing accessible to everyone and even more so to potential consumers among nationals. This is what makes it a profitable business when compared to the old approach. Products can be branded but cannot be successful if marketing is only waiting for those who offer conventional means. However, with a new design based on digital technology, it will be even more crowded in the future because information related to HR products and services is already useful. Businesses in Indonesia lack a way of life for new things, but not everyone can get data on designing innovative business practices (Kanter, 2010).

It could be because the cost factor is prohibitive if it involves technology. However, compared to consumers who have to visit every production location, this is not possible, especially now that it is still a pandemic era. To get information about the product, prospective buyers will undoubtedly think of coming manually. So web-based cultural promotion and service business units might be very acceptable if technology could make it easier for all data to be obtained from technology websites. So without technology, not many can hope to rise to compete. The arrangement is to carry out promotions and online transactions for business deals such as data for business people who want to think about it. Currently, it is relatively widely available online (Womack \& Jones, 2015).

Of course, business people will build a clothing business civilization if technology adoption can be maximized. Real consumers and business people must provide technology pages to help meet potential consumers with producers through technology handled by reliable human resources committed to advancing. For this research, we will examine the supporting data to get a new understanding of how business in Indonesia can run with the adoption of technology that is covered by excellent HR and business objectives can be maximally achieved. Haseeb et al. (2019) said that the role of social networking had challenged technological change in achieving a sustainable competitive advantage and sustainable business performance.

\section{Method}

This study's core objective is to understand the implications of technical information to improve human business resources in Indonesia. For that purpose, we have collected data from publications with opposition from 2010 to 2021. After the data is collected, we then analyze it with a phenomenological approach so that we get an answer to the study with valid and reliable principles. Before we can get the existing data findings, we have to understand the questions; we involve coding, in-depth evaluation, and concluding findings data in the data analysis process. We prioritize secondary data with a descriptive qualitative approach with guidance as much as data from Google scholars, ERIC publications, Google Docs, and other sources. Experts join our study guide in reviewing technology and application studies in midwives' social studies (Ridder, 2014).

\section{Result and Discussion}

The implications of technology in improving human resources for business activities in Indonesia were done by Winasis et al. (2020) to transform sustainable technology in the banking business, impacting increasing banking employees. The changes currently taking place in Indonesia's banking industry stem from a fundamental concern for bank organizations. Because the framework and conditions that have been running regularly for a long time must be changed significantly, namely through the application of technology for internal use and customer service, even though this technology has side effects, the advancement of the banking business career still has a direct impact on the psychological condition of the players. The results show that private banks' audit drive that has completed one year of technology development-based changes has a positive proposition for advancing their own banking business.

That is the study of Yuliansyah et al. (2016) who examined how business methods and implementation in various organizations and companies in Indonesia. Their studies prove that more and more associations are laying the 
fundamentals of technology-based business operations to believe that technology implementation will help companies create profitable business areas. They want to adopt technology even though it is expensive, assuming that technology can solve the problem by seeing the association's performance increase. Another reason concerns the increasingly globalized business climate and institutional and socio-social environmental issues in Indonesia. Their study found that affiliates have tried basic isomorphism by considering the share of consumer desires and integrated into the adoption of technology with significant value in increasingly digital customer service and demands for enterprise efficiency and superior customer service.

Rahayu \& Day (2015) findings on how technology brings business with customers online in several SMEs in developing countries, including Indonesia, was essential. Several SMEs' Web-based business decisions are very appropriate considering that previously the condition of technology had not developed. The current condition shows that many businesses have become advanced and successful because they have adopted the technology. However, to have an alternative to adopting technology, there are many financial sacrifices, namely businesses and associations, including SMEs, which have minimal funding to receive internet service-based businesses. This study relies on an investigation of 292 SMEs in Indonesia and found that the benefits of technological applications such as level of development, owner's imagination, and owner's IT limitations are the main components.

Tambunan \& Rosdiana (2020) examine the Indonesian tax office government's steps to face digital economy taxation challenges. This study combines the viewpoint of constructivism and qualitative examination techniques. Findings were obtained through establishment surveys, documentation studies, and participatory meetings. The latest data shows that from the business point of view, the Indonesian government believes that technology adoption changes are fundamental and potentially supported by efforts to improve customer service through specialist technology applications concerning economic progress entering the advanced era. The study flows in the April 2013 edition of the tax and accounting diary with digitalization efforts.

Meanwhile, in their study, Nurmandi \& Kim (2015) made e-work on work in the internal structure of services to achieve decentralization by evaluating three Indonesian metropolitan organizations. The motivation that drives this paper is to examine e-recruitment activities within decentralization in government structures in Indonesia. This evaluation focused on three urban village governments in Indonesia - Yogyakarta City, Tangerang, and Kutaikartanegara Regency. The main finding of this assessment is that HR is the bottom line that selects the environmental presentation of re-acquiring in the three metropolitan districts. Thus, customer service can be improved after e-receipt becomes part of HR work in the administration environment.

Mardiah \& Basri (2013) studied the game plan system to reduce waiting time for outpatients in Indonesia's public clinical facilities. Together, the prolonged treatment program in the outpatient room system followed by a short conversation has long been a difference of opinion. The clinical facility line model uses a single channel multiphase structure. The coating theory is the main instrument to see patients openly holding events for each worker. Implementing an 'accessible expert to come to work' system may appear to reduce expert idle time but results in a high incidence of patient delay. It is hoped that the examination will provide an overview of the critical purpose behind the time frame for patients to undergo clinical care in an outpatient office in one of the public crisis facilities in Indonesia and provide suggestions on the best approach to improving the structure of the plan.

Tambunan \& Rosdiana (2020) examine the Indonesian tax office government's steps to face digital economy taxation challenges. This study combines the viewpoint of constructivism and effective examination techniques. Findings were obtained through establishment surveys, documentation studies, and participatory meetings. The latest data shows that from the business point of view, the Indonesian government believes that technology adoption changes are fundamental and potentially supported by efforts to improve customer service through specialist technology applications concerning economic progress entering the advanced era. The study flows in the April 2013 edition of the tax and accounting diary with digitalization efforts.

Meanwhile, in their study, Nurmandi \& Kim (2015) made e-work on work in the internal structure of services to achieve decentralization by evaluating three Indonesian metropolitan organizations. The motivation that drives this paper is to examine e-recruitment activities within decentralization in government structures in Indonesia. This evaluation focused on three urban village governments in Indonesia - Yogyakarta City, Tangerang, and Kutai Kartanegara Regency. The main finding of this assessment is that HR is the bottom line that selects the environmental presentation of re-acquiring in the three metropolitan districts. Thus, customer service can be improved after e-receipt becomes part of HR work in the administration environment.

Mardiah \& Basri (2013) studied the game plan system to reduce waiting time for outpatients in Indonesia's public clinical facilities. Together, the prolonged treatment program in the outpatient room system followed by a short conversation has long been a difference of opinion. The clinical facility line model uses a single channel multiphase structure. The coating theory is the main instrument to see patients openly holding events for each worker. 
Implementing an 'accessible expert to come to work' system may appear to reduce expert idle time but results in a high incidence of patient delay. It is hoped that the examination will provide an overview of the critical purpose behind the time frame for patients to undergo clinical care in an outpatient office in one of the public crisis facilities in Indonesia and provide suggestions on the best approach to improving the structure of the plan.

\section{Discussion}

This section will discuss the findings of this study's data, which aims to understand the implications of digital transformation in human resource development in domestic business practices. To get this understanding, we have reviewed 40 papers and present ten publications that have examined various digital applications and transformation issues in improving human resources and best practice business services from various application contexts.

Based on the above findings data, we can understand that the ten publications have confirmed that the technology application has been able to bring about significant changes in human resources in each organization in internal and consumer services. The majority of industries and organizations' choice to adopt technology and replace humans' role is all due to the principle of the effectiveness of service systems provided by technology in the current competitive era. A study on the effectiveness and technological innovation in public services and strengthening collaboration between organizations were carried out by Eprilianto et al. (2020) with the theme of digital studies of public sector innovation; the point of collaboration effectiveness in implementing digital with innovation. Another finding that successfully discussed the theme of technology implementation in the HR service sector was Rezky et al. (2019), Sudarmo et al. (2021) who understands how the young millennial generation must welcome the era of digital technology and innovation in educational services by improving Indonesia's human resources. Two examples of studies can convince the author of how useful technological transformation is in Indonesia's public service circles.

Most of this study's findings confirm that technological innovation and transformation can be in many application contexts. However, in simple terms, the most critical aspect of technology and innovation is that every innovation always strives to prioritize the principles of benefits and benefits of applying technology in supporting and even delegating people in serving businesses and organizations better. Every day, there are more and more efforts to transform and innovate technology to encourage public services' acceleration by supporting human resources towards best business practices. Because various technology providers with low cost and minimize risk will make technology increasingly inhuman demand in business practice.

These technological applications and innovations include technological innovations such as software and hardware. These can assist people in all business activities such as banking services, education, and other public services. Such a study was also carried out by Rønning et al. (2014) in their study framing innovation in the public sector towards an era of efficiency and productivity as the ultimate goal of every organization and industry. Beyond the above studies, Deichmann et al. (2016) instead examined whether technology transformation would enter the agricultural sector in developing countries. Seeing the trends and public demands, this kind of innovation and transformation will continue to the non-office business sector and jobs such as agriculture and marine.

\section{Conclusion}

In this final section, we will summarize the findings and results of this study which aims to understand the implementation of technological transformation in improving and delegating human resources in the business and public service sector in Indonesia. By considering data and reviewing dozens of publications, we can conclude that, on average, organizations that have successfully applied technology and their service environment are due to the effectiveness and productivity of technology in serving the public and internal business itself. Based on the above analysis, application and technology transformation helps increase human resources in various sectors, including banking, education, government organizations, non-government organizations, and other business services. With the changing times, the presence of technology in continuous innovation for efficiency and productivity of the public's business and services can no longer be held back. So this is the era of technology human friends towards civilization and digital.

\section{Acknowledgments}

Thank you all; we are countless writers on all the feedback from the beginning until this paper has been carried out successfully. Likewise, we assisted our team in carrying out services on our duties with financial assistance and other assistance. For all this, we say thousands of thanks. 


\section{References}

Bhanot, S. (2012). Use of social media by companies to reach their customers. SIES Journal of Management, 8(1).

Bratton, J., \& Gold, J. (2017). Human resource management: Theory and practice. Palgrave.

Baum, T. (2015). Human resources in tourism: Still waiting for change?-A 2015 reprise. Tourism Management, 50, 204-212. https://doi.org/10.1016/j.tourman.2015.02.001

Briscoe, D. (2004). International human resource management: Policies and practices for multinational enterprises. Routledge.

Campbell, B. C., Mitchell, P. J., Kleinig, T. J., Dewey, H. M., Churilov, L., Yassi, N., Yan, B., Dowling, R. J., Parsons, M. W., \& Oxley, T. J. (2015). Endovascular therapy for ischemic stroke with perfusion-imaging selection. New England Journal of Medicine, 372(11), 1009-1018.

Capnary, M. C., Rachmawati, R., \& Agung, I. (2018). The influence of flexibility of work to loyalty and employee satisfaction mediated by work life balance to employees with millennial generation background in Indonesia startup companies. Business: Theory and Practice, 19, 217-227.

Cardon, M. S., \& Stevens, C. E. (2004). Managing human resources in small organizations: What do we know?. Human resource management review, 14(3), 295-323. https://doi.org/10.1016/j.hrmr.2004.06.001

Chen, L., Evans, T., Anand, S., Boufford, J. I., Brown, H., Chowdhury, M., ... \& Wibulpolprasert, S. (2004). Human resources for health: overcoming the crisis. The Lancet, 364(9449), 1984-1990. https://doi.org/10.1016/S0140$6736(04) 17482-5$

Cascio, W. F. (2015). Managing human resources. McGraw-Hill New York.

Dalenogare, L. S., Benitez, G. B., Ayala, N. F., \& Frank, A. G. (2018). The expected contribution of Industry 4.0 technologies for industrial performance. International Journal of Production Economics, 204, 383-394.

Deichmann, U., Goyal, A., \& Mishra, D. (2016). Will digital technologies transform agriculture in developing countries? The World Bank.

DiPietro, R. B., \& Wang, Y. R. (2010). Key issues for ICT applications: Impacts and implications for hospitality operations. Worldwide Hospitality and Tourism Themes.

Drew, J., McCallum, B., \& Roggenhofer, S. (2016). Journey to lean: Making operational change stick. Springer.

Eprilianto, D. F., Pradana, G. W., \& Sari, Y. E. K. (2020). Digital inovasi sektor publik: Efektivitas kolaborasi dalam implementasi inovasi dega digital. Jurnal El-Riyasah, 10(2), 127-145.

Fenech, R., Baguant, P., \& Ivanov, D. (2019). The changing role of human resource management in an era of digital transformation. Journal of Management Information and Decision Sciences, 22(2), 1-10.

Fountain, J. E. (2004). Building the virtual state: Information technology and institutional change. Brookings Institution Press.

Gibler, K. M., \& Lindholm, A.-L. (2012). A test of corporate real estate strategies and operating decisions in support of core business strategies. Journal of Property Research, 29(1), 25-48.

Gupta, S., Leszkiewicz, A., Kumar, V., Bijmolt, T., \& Potapov, D. (2020). Digital analytics: Modeling for insights and new methods. Journal of Interactive Marketing, 51, 26-43.

Harmon, P., \& Trends, B. P. (2010). Business process change: A guide for business managers and BPM and Six Sigma professionals. Elsevier.

Haron, R. (2016). Do Indonesian firms practice target capital structure? A dynamic approach. Journal of Asia Business Studies.

Haseeb, M., Hussain, H. I., Kot, S., Androniceanu, A., \& Jermsittiparsert, K. (2019). Role of social and technological challenges in achieving a sustainable competitive advantage and sustainable business performance. Sustainability, 11(14), 3811.

Hotho, S., \& Champion, K. (2011). Small businesses in the new creative industries: Innovation as a people management challenge. Management Decision.

Hsu, P.-F., Ray, S., \& Li-Hsieh, Y.-Y. (2014). Examining cloud computing adoption intention, pricing mechanism, and deployment model. International Journal of Information Management, 34(4), 474-488.

Ismail, M. H., Khater, M., \& Zaki, M. (2017). Digital business transformation and strategy: What do we know so far. Cambridge Service Alliance, 10.

Jeong, J.-S., Lee, S.-H., \& Lee, S.-G. (2017). Korean Wave| When Indonesians Routinely Consume Korean Pop Culture: Revisiting Jakartan Fans of Korean Drama Dae Jang Geum. International Journal of Communication, $11,20$.

Kanter, R. M. (2010). Supercorp: How vanguard companies create innovation, profits, growth, and social good. Profile Books. 
Kavanagh, M. J., \& Johnson, R. D. (2017). Human resource information systems: Basics, applications, and future directions. Sage Publications.

Komninos, N. (2006). The architecture of intelligent clities: Integrating human, collective and artificial intelligence to enhance knowledge and innovation. 2006 2nd IET International Conference on Intelligent Environments-IE $06,1,13-20$.

Kosasih. (2019). Creating Competitive Advantages for Companies by Developing Strategic Human Resource Management in the Face of the Challenges of the Revolution 4.0. International Journal of Science and Society (IJSOC), 1(4), 103-112.

Krasnov, S., Sergeev, S., Titov, A., \& Zotova, Y. (2019). Modelling of digital communication surfaces for products and services promotion. IOP Conference Series: Materials Science and Engineering, 497(1), 012032.

Lewandowski, M. (2016). Designing the business models for circular economy-Towards the conceptual framework. Sustainability, 8(1), 43.

Loebbecke, C., \& Picot, A. (2015). Reflections on societal and business model transformation arising from digitization and big data analytics: A research agenda. The Journal of Strategic Information Systems, 24(3), 149157.

Malik, A. (2019). Creating competitive advantage through source basic capital strategic humanity in the industrial age 4.0. International Research Journal of Advanced Engineering and Science, 4(1), 209-215.

Mardiah, F. P., \& Basri, M. H. (2013). The analysis of appointment system to reduce outpatient waiting time at Indonesia's public hospital. Human Resource Management Research, 3(1), 27-33.

Mazzone, D. M. (2014). Digital or death: Digital transformation: the only choice for business to survive smash and conquer. Smashbox Consulting Inc.

McKerchar, M., \& Evans, C. (2009). Sustaining growth in developing economies through improved taxpayer compliance: Challenges for policy makers and revenue authorities. EJTR, 7, 171.

Miles, R. E., \& Snow, C. C. (1984). Designing strategic human resources systems. Organizational dynamics, 13(1), 36-52. https://doi.org/10.1016/0090-2616(84)90030-5

Montecchi, M., Plangger, K., \& Etter, M. (2019). It's real, trust me! Establishing supply chain provenance using blockchain. Business Horizons, 62(3), 283-293.

Morkunas, V. J., Paschen, J., \& Boon, E. (2019). How blockchain technologies impact your business model. Business Horizons, 62(3), 295-306.

Noe, R. A., Hollenbeck, J. R., Gerhart, B., \& Wright, P. M. (2017). Human resource management: Gaining a competitive advantage. McGraw-Hill Education New York, NY.

Nurmandi, A., \& Kim, S. (2015). Making e-procurement work in a decentralized procurement system: A comparison of three Indonesian cities. International Journal of Public Sector Management.

Palmer, T. B., \& Flanagan, D. J. (2016). The sustainable company: Looking at goals for people, planet and profits. Journal of Business Strategy.

Parviainen, P., Tihinen, M., Kääriäinen, J., \& Teppola, S. (2017). Tackling the digitalization challenge: How to benefit from digitalization in practice. International Journal of Information Systems and Project Management, 5(1), 63-77.

Putra, P., Mizani, H., Basir, A., Muflihin, A., \& Aslan, A. (2020). The Relevancy on Education Release Revolution 4.0 in Islamic Basic Education Perspective in Indonesia (An Analysis Study of Paulo Freire's Thought). Test Engineering \& Management, 83, 10256-10263.

Rahayu, R., \& Day, J. (2015). Determinant factors of e-commerce adoption by SMEs in developing country: Evidence from Indonesia. Procedia-Social and Behavioral Sciences, 195, 142-150.

Reis, J., Amorim, M., Melão, N., \& Matos, P. (2018). Digital transformation: A literature review and guidelines for future research. World Conference on Information Systems and Technologies, 411-421.

Remund, D. L. (2010). Financial literacy explicated: The case for a clearer definition in an increasingly complex economy. Journal of Consumer Affairs, 44(2), 276-295.

Rezky, M. P., Sutarto, J., Prihatin, T., Yulianto, A., \& Haidar, I. (2019). Generasi Milenial yang Siap Menghadapi Era Revolusi Digital (Society 5.0 dan Revolusi Industri 4.0) di Bidang Pendidikan Melalui Pengembangan Sumber Daya Manusia. Prosiding Seminar Nasional Pascasarjana (PROSNAMPAS), 2(1), 1117-1125.

Ridder, H.-G. (2014). Book review: Qualitative data analysis. A methods sourcebook (Vol. 28). Sage publications Sage UK: London, England.

Rønning, R., Enquist, B., \& Fuglsang, L. (2014). Framing innovation in public service sectors. Routledge.

Rosadi, S. D., \& Tahira, Z. (2018). Consumer protection in digital economy era: Law in Indonesia. Yustisia Jurnal Hukum, 7(1), 81. 
Schuler, R., \& Jackson, S. E. (2014). Human resource management and organizational effectiveness: Yesterday and today. Journal of Organizational Effectiveness: People and Performance.

Schuler, R. S. (1992). Strategic human resources management: Linking the people with the strategic needs of the business. Organizational dynamics, 21(1), 18-32. https://doi.org/10.1016/0090-2616(92)90083-Y

Schwertner, K. (2017). Digital transformation of business. Trakia Journal of Sciences, 15(1), 388-393.

Scott, J. T. (2017). The sustainable business: A practitioner's guide to achieving long-term profitability and competitiveness. Routledge.

Sudarmo, Nugraha, M. S., Mardhiah, R. I.liow, F. E., \& Aslan. (2021). The Identification of Online Strategy Learning Results While Students Learn from Home During the Disruption of the COVID-19 Pandemic in Indonesia. Journal of Contemporary Issues in Business and Government, 27(2), 1950-1956. https://doi.org/10.47750/cibg.2021.27.02.205

Tambe, P., Cappelli, P., \& Yakubovich, V. (2019). Artificial intelligence in human resources management: Challenges and a path forward. California Management Review, 61(4), 15-42.

Tambunan, M. R., \& Rosdiana, H. (2020). Indonesia Tax Authority Measure on Facing the Challenge in Taxing Digital Economy. The International Technology Management Review, 9(1), 1-10.

Thakur, S. P. (1999). Size of investment, opportunity choice and human resources in new venture growth: Some typologies. Journal of Business Venturing, 14(3), 283-309. https://doi.org/10.1016/S0883-9026(98)00002-0

Tarabasz, A., Selaković, M., \& Abraham, C. (2018). The classroom of the future: Disrupting the concept of contemporary business education. Entrepreneurial Business and Economics Review, 6(4), 231.

Tyson, S. (2014). Essentials of human resource management. Routledge.

Vermesan, O., \& Friess, P. (2013). Internet of things: Converging technologies for smart environments and integrated ecosystems. River publishers.

Westerman, G., Bonnet, D., \& McAfee, A. (2014). Leading digital: Turning technology into business transformation. Harvard Business Press.

Winasis, S., Riyanto, S., \& Ariyanto, E. (2020). Digital Transformation in Indonesian Banking Industry: Impact on Employee Engagement. International Journal of Innovation, Creativity and Change, Pending for Published March, 2020.

Womack, J. P., \& Jones, D. T. (2015). Lean solutions: How companies and customers can create value and wealth together. Simon and Schuster.

Yuliansyah, Y., Rammal, H. G., \& Rose, E. (2016). Business strategy and performance in Indonesia's service sector. Journal of Asia Business Studies. 